\title{
Čemu humanističke u vrijeme dominacije prirodnih znanosti?**
}

Ivan Kordićc

ivan.kordic1@zg.htnet.hr
UDK: $168.521: 168: 522$

165.0

Prethodno priopćenje / Preliminary communication

Primljeno: 11. prosinca 2015.

Prihvaćeno: 29. veljače 2016.

Pri pitanju o humanističkim znanostima u vrijeme dominacije prirodnih čini se nužnim prije svega postaviti pitanje o čovjekovu znanju i o njegovu mišljenju uopće. Pritom se možda brzo može doći do uvida da ovo pitanje ne podnosi jednostavne $i$ jednostrane odgovore, o čemu svjedoči ne samo povijest znanja $i$ mišljenja, povijest znanosti i filozofije sa svom njihovom beskonačnom neiscrpivošću, nego i u modernom svijetu - unatoč svom znanju - snažno prisutno uvjerenje da čovjek $i$ njegov svijet ipak ostaju velika, zagonetna tajna. Stoga su $i$ moderne prirodne i duhovne znanosti i u svojim metodama $i$ u svojim spoznajama uvelike nesigurne, koliko god one nerijetko hinile sigurnost $i$ koliko god, osobito prirodne, imale potrebu svjesno ili nesvjesno ostaviti dojam apsolutne $i$ neupitne dominacije. A da bi i jedne i druge mogle dati svoj prilog razumijevanju i spoznavanju onoga što jest, potrebno je što je najviše moguće odreći se ideološko-dogmatskih zabluda prošlosti i sadašnjosti i okrenuti se hermeneutičko-fenomenološkom traganju za istinom bitka, s punom sviješću da je ona vremenita i povijesna, konačna i ograničena, da se ona čovjeku na razne načine $i$ uvijek nanovo i skriva i pokazuje.

Ključne riječi: humanističke znanosti, prirodne znanosti, znanje, mišljenje, istina.

\footnotetext{
* Izlaganje na znanstvenom skupu Instituta za filozofiju s temom: »Smisao humanističkih znanosti«, a održanom u Palači Matice hrvatske u Zagrebu, 10. prosinca 2015. Cjelovit rad će biti objavljen u zborniku skupa.

**:Dr. sc. Ivan Kordić je redoviti profesor u trajnom izboru, znanstveni savjetnik na Institut za filozofiju, Ulica grada Vukovara 54, HR-10000 Zagreb.
} 
Teško je osporiti danas sve prisutnije uvjerenje da se moderni čovjek nalazi u krizi identiteta kao nikada dosada, koja ga čini nesigurnim, pa čak i bespomoćnim. Naslijeđeni svjetonazori i životni modeli nestaju, a novi se ne pronalaze, možda i ne traže, budući da se nerijetko čini da je besmisleno i tražiti ih. A kao nadomjestak za sve to nerijetko se nude prirodne i tehničke znanosti i njihovi proizvodi, a svako razmišljanje, koje se tome ne želi podložiti, prešutno se ili glasno proglašava bespredmetnim, dok se filozofija, ako uopće želi biti ozbiljno shvaćena i imati smisla, treba baviti logičkim razjašnjavanjem iskaza tih znanosti, gotovo prihvatiti ulogu njihove služavke, biti »ancilla scientiae«, kao što je nekada bila »ancilla theologiae«.

Poznato je da je ovu logičko-razjašnjavajuću ulogu filozofije, osobito u prvoj fazi svojih misaonih pokušaja, jasno formulirao Wittgenstein tvrdeći da ona »nije nikakva nauka nego djelatnost«, da njezin rezultat »nisu 'filozofske rečenice', nego razjašnjenje rečenica«, da ona nejasne misli treba »učiniti jasnima i oštro ih razgraničiti«. ${ }^{1}$ No, ova se njegova razmišljanja često shvaćaju kao propusnicu za sve moguće i nemoguće oblike scijentizma, pozitivizma i empirizma. Pritom se prešućuje njegova skepsa prema apsolutiziranju prirodnih znanosti. Prešućuje se naime da je on tvrdio i to da u temelju cijelog modernog svjetonazora stoji zavaravanje da su »takozvani prirodni zakoni razjašnjenja prirodnih pojava« i da ova razjašnjenja žele ostati kod zakona kao »nečega što je nedodirlivo«, kao što su stariji ostajali »kod Boga i sudbine«. A u oba slučaja riječ je o nečemu što je više od znanstvenog razjašnjenja stvarnosti, o uvjerenjima koja se ne mogu verificirati ni logički ni empirijski, odnosno znanstveno. Pritom mu se čini da su oni koji vjeruju u Boga ili u sudbinu »utoliko jasniji ukoliko priznaju jasan zaključak«, prema kojem ono neobjašnjeno i neobjašnjivo prihvaćaju vjerom, »dok se u novom sustavu«, u pozitivističkom razjašnjavanju prirode, »treba činiti kao da je sve razjašnjeno «. ${ }^{2}$ Tako su »stariji« o stvarnosti zapravo donijeli zaključak koji se ne može verificirati, dok »razjasnitelji prirode« sebi umišljaju da su sve »razjasnili«.

Wittgenstein je dakle očito mišljenja da ni logički razjašnjene rečenice ni prirodoznanstvene spoznaje ne mogu razjasniti sve ono što čovjeka zanima i što bi želio znati.

A prema Heideggeru se apsolutiziranjem prirodnih znanosti nerijetko niječe sve ono što nije na neki način pozitivno dostupno, pretvara ga se u ništa, pušta se da »na logičkom putu sve potone u nihilizam koji je zapravo izmišljen uz pomoć logike«. Pritom mu se postavlja pitanje vodi li »ono 'protiv', koje neko mišljenje iznosi nasuprot onom što je izrečeno«, nužno "prema pukoj negaciji«, koja isključuje mogućnost nečega drugoga odnosno trećega, a koja svoju

\footnotetext{
${ }^{1}$ Ludwig WITTGENSTEIN, Tractatus logico-philosophicus. Logisch-philosophische Abhandlung, Frankfurt a. M., Suhrkamp, 1979, 41. U daljnjem tekstu navodi prije bilješke odnose se na stranicu naznačenu u bilješci.

${ }^{2}$ Isto, 110.
} 
isključivost crpi iz logičkog načela protuslovlja, misleći u dihotomiji da ili ne, koja istinu vidi samo u sudu i u tradicionalnom načelu adekvacije? A ovakvo se isključivanje trećega prema njemu događa i zbog toga što se ne dopušta nikakav slobodan pogled, drukčije mišljenje, što se ono postavljeno i predočeno vidi »kao 'ono pozitivno', pa se polazeći od njega apsolutno i negativno odlučuje o području mogućih suprotnosti«. Pritom zapravo do izražaja dolazi odustajanje od toga da se ovo "pozitivno' zajedno s pozicijom i opozicijom« izloži istinskom promišljanju. A možda bi tek takvo promišljanje moglo dovesti do uvida da se stalnim pozivanjem na ono logično stvara privid kao da se netko »upušta u mišljenje, dok se zapravo odrekao mišljenja « ${ }^{3}$ i otvoriti put prema mišljenju stvarnosti u svoj njezinoj pokazanosti i zagonetnosti, neskrivenosti i skrivenosti, pri čemu ne bi mogla biti zaboravljena činjenica da je svako znanje ipak i neznanje.

Ovakvo bi mišljenje prema Heideggeru omogućilo da se pitanje o biću kao onom pozitivnom "postavi na svoj temelj, na pitanje o istini bitka ${ }^{4}{ }^{4}$ a obzor razumijevanja bića u smislu predočavajućega mišljenja ponovno vrati »na područje utemeljenja istine bitka«, dakle »u tu-bitak«, na područje koje se u fenomenološkom pristupu onome što jest pokazuje kao bitak-u-svijetu, koji cjelinu bitka i čovjekova tubitka naslućuje i misli u njihovoj uzajamnoj pripadnosti, bez logičko-pozitivističke jednostranosti. A jednim takvim pristupom logika kao nauka o ispravnom mišljenju mogla bi postati »promišljanje jezika kao zasnivajućeg imenovanja istine bitka u njezinoj neiscrpivosti, tako da se bitak, koji je u tradicionalnoj metafizici promišljan i shvaćan prije svega kao ono što je najopćenitije i najuobičajenije, pokaže kao ono što je zapravo »najjedinstvenije i najneuobičajenije.$^{5}$

Ovdje se Heideggeru postavlja i pitanje je li mišljenje, koje bi promišljalo istinu bitka i tubitak čovjeka kao egzistenciju u njezinoj pripadnosti bitku, samo »teorijsko predočavanje bitka i čovjeka« ili se iz njega mogu preuzeti i upute za čovjekov djelatni život? Pritom tvrdi da ono »nije ni teorijsko ni praktično«, jer se događa »prije ovoga razlikovanja«. Ono naime prije svega misli bitak i ne traga za nekim spoznatliivim rezultatom i djelovanjem, pri čemu bitku pripada njemu »primjereno kazivanje«, čija je sigurnost veća »od sigurnosti znanosti« i znanja o biću, ali i »slobodnija od bilo koje druge, budući da ona pušta »bitak - da bude « ${ }^{6}$ bitak, da ono što jest doista bude ono što jest.

Stoga ovakvo mišljenje, ovakvo filozofiranje za Heideggera nije nikakav šepajući »dodatak općim predodžbama« o već poznatom biću i o znanju o njemu, nego prethodno, »otvarajuće znanje o biti stvari«, a ta »bit se uvijek nanovo

\footnotetext{
${ }^{3}$ Martin HEIDEGGER, Über den Humanismus, Frankfurt a. M., Vittorio Klostermann, ${ }^{8} 1981$, 38.

${ }^{4}$ Martin HEIDEGGER, Beiträge zur Philosophie (vom Ereignis), Frankfurt a. M., Vittorio Klostermann, ${ }^{2} 1994,176$.

${ }^{5}$ Isto, 177.

${ }^{6}$ Heidegger, Über den Humanismus..., 48.
} 
skriva«. Stvari su naime u svojoj biti uvijek i poznate i nepoznate, pa se znanje o njima ne može učiniti neposredno korisnim, budući da se za njim i ne traga zbog koristi. No, ovo mišljenje unatoč tome može djelovati posredno. Ono naime cjelokupnom ljudskom ponašanju i odlučivanju »otvara nove poglede i mjerila« i »ovladava držanjem i djelovanjem povijesnog tubitka čovjeka«, puštajući ga da u svom bitku bude, misli i zna ono što jest, bez ideoloških fiksacija. Pa ako se filozofija ovako razumije, onda se može reći da je ona, doduše, »neposredno beskorisno, ali ipak ovladavajuće znanje o biti stvari«. A bit, bitak stvari, bit bitka i bića, ipak je ono što je »najdostojnije pitanja«. Pa ako se filozofija u svom propitivanju stvarnosti bori za »dostojanstvo onoga što je najdostojnije pitanja« i ne teži za određenim rezultatima, onda se čini neizbježnim da ona »mišljenju koje je usmjereno prema obračunavanju, iskorištavanju i učljivosti uvijek ostaje strana«.

Budući naime da moderne znanosti teže prema tehniziranju, organiziranju i iskorištavanju stvarnosti, a »prema javnom prividu prvenstveno i jedino one posjeduju 'znanje'«, onda se u njima nerijetko događa i »otuđenje u odnosu na filozofiju« i dokazivanje »njezine suvišnosti«. ${ }^{7}$ Pa iako je ovo dokazivanje neutemeljeno, ono ipak kod suvremenog mislećeg čovjeka nerijetko može izazivati osjećaj manje vrijednosti. Stoga je prema Heideggeru nužno steći uvid u činjenicu da ovaj osjećaj nema temelja $u$ istinskoj filozofiji. Ako naime mislilac ima iskustvo da u filozofiji ne postiže nikakav uspjeh, da s njom ne može »ništa započeti«, onda se on zbog toga ne treba nikome ispričavati, nego i samome sebi i drugima samouvjereno priznati da je to doista tako, da je riječ o tvrdnji »koja ima svoju neospornu ispravnost«. Inače bi se mogao učvrstiti, pa i povećati nesporazum koji je u predrasudi da je »filozofiju moguće procjenjivati prema mjerilima svakodnevnice ${ }^{8}{ }^{8}$ Nije dakle sporno da se s filozofijom ne može ništa započeti, no time o njoj još nije izrečena puna istina. Može naime biti da ona sama može »s nama nešto « započeti, dakako "pod pretpostavkom da se u nju upustimo «, ${ }^{9}$ da osluškujemo ono što je ona u svojoj biti, što ona može i treba biti.

Pritom valja prije svega znati da znanosti istražuju samo biće i da one na osnovi svog istraživanja dolaze do rezultata, što vrijedi i za metamatiku i za prirodne i nerijetko za, unatoč svim razlikama, duhovne znanosti. Jer, i one, kao i prirodne, stoje na tlu naslijeđene zapadnjačke filozofije u njezinu metafizičkom obliku, pa tematiziraju, objektiviraju i pokušavaju, prema Heideggeru, spoznati samo biće, a zaboravljaju bitak, one njega ne žele niti mogu misliti, pa su one samo »upad... u cjelinu bića«, one se odnose na »biće samo - i ništa

\footnotetext{
7 Martin HEIDEGGER, Aus der Erfahrung des Denkens, GA 13, Frankfurt a. M., Vittorio Klostermann, 1983, 18.

${ }^{8}$ Martin HEIDEGGER, Einführung in die Metaphysik, Tübingen, Max Niemeyer Verlag, ${ }^{3} 1966$, 9.

${ }^{9}$ Isto, 10.
} 
drugo«. Pritom se misliocu postavlja pitanje kako »stoji s Ničim?«, ${ }^{10}$ postavlja mu se pitanje o »ničemu«, koje se ne razumijeva kao niječno »ništa«, nego kao ono što je i skriveno i neskriveno, što je i ništa i bitak, za što može biti otvoreno samo mišljenje koje ni kao znanost ni kao filozofija nije uobličeno u metafizici, nego je mišljenje bitka za razliku od mišljenja i znanja o biću.

A budući da je ovdje riječ o mišljenju koje prema Heideggeru dosada nije mišljeno, ono je na sebe navuklo mnoge nesporazume i neprimjerena tumačenja, zbog čega je on uvijek nanovo pokušavao razjasniti da se on pri pitanju o »ničemu« ne pita o nečem neodređenom, nego o tome kako stoji »s ovim sasvim drukčijim u odnosu na biće«, kako stoji »s onim što nije biće «, ${ }^{11}$ s onim što je i bitak i ništa. I budući da znanosti na osnovi svoje orijentacije prema biću, ovo sasvim drukčije ne mogu shvatiti, one ga odbacuju i žrtvuju kao nešto »ništavno «. ${ }^{12}$ No, da bi se ovo »ništavno«, ovu »ništavnost«, moglo istinski razumjeti, nužno je prije toga pokušati razumjeti smisao bitka.

Za Heideggera je dakle mišljenje na prvom mjestu mišljenje bitka, a ne bića koje je prije svega predmet znanstvenog istraživanja i znanja. No, poznato je da se ovo njegovo razumijevanje znanosti i njezine uloge pri spoznavajućem pristupu stvarnosti nerijetko odbacuje kao neprimjereno, iako je činjenica da je on intenzivno komunicirao s najpoznatijim matematičarima i fizičarima svoga vremena, s Oskarom Beckerom, Wernerom Heisenbergom i Carl-Friedrich von Weizsäckerom. ${ }^{13}$ A razlog i dokaz za opravdanost ovoga odbacivanja za mnoge je njegova tvrdnja da »znanost ne misli«. No, i sam je svjestan da je ova njegova rečenica »sporna «, ${ }^{14}$ pa ju je uvijek nanovo pokušavao razjasniti. Pritom ističe da su pojedinačni istraživači možda u stanju »misliti«, ali »ne metodom njihova istraživanja kao znanstvenikâ, kao onih koji se bave znanošću«, kao spoznavatelja bića, nego kao oni koji misle bitak. Osim toga, on uvijek nanovo naglašava da njegova tvrdnja da znanost ne misli nije nikakva »prezirna prosudba«. Ova naime tvrdnja nije »nikakvo utvrđivanje neke činjenice«, nego »određenje biti«, prema kojem znanost »kao temu nema način bivstvovanja njezina područja kao takvoga «, njegova bitka, i da ga »ne može imati «. ${ }^{15}$ Znanost, naime, unutar svojih granica ne može određivati bit svoga područja istraživanja, budući da ono što je u njoj uvijek nezaobilazno - npr. priroda, čovjek, povijest, jezik, odnosno njihova bit - za nju i putem nje ostaje »nedostupno«. ${ }^{16}$

\footnotetext{
${ }^{10}$ Martin HEIDEGGER, Was ist Metaphysik?, Frankfurt a. M., Vittorio Klostermann, ${ }^{16} 2007,28$.

${ }^{11}$ Martin HEIDEGGER, Wegmarken, Frankfut a. M., Vittorio Klostermann, ${ }^{2} 1978,412$.

${ }^{12}$ Heidegger, Was ist Metaphysik?..., 29.

${ }^{13}$ Usp. isto, 141.

${ }^{14}$ Martin HEIDEGGER, Was heißt Denken?, GA 8, Frankfurt a. M., Vittorio Klostermann, 2002, 9.

${ }^{15}$ Isto, 9a.

${ }^{16}$ Martin HEIDEGGER, Vorträge und Aufsätze, GA 7, Frankfurt a. M., Vittorio Klostermann, 2000,60 .
} 
Tako, prema Heideggeru, npr. masa, sila, brzina, gibanje, mjesto i vrijeme s obzirom na polje znanosti koja istražuje ove sadržaje daju dostatnu karakteristiku. No, ostaje nejasno što ovi pojmovi znače u svojoj biti. Oni naime figuriraju kao najopćenitiji pojmovi u odnosu na biće, no o onome »na što se u ovim pojmovima misli, dalje se ne propituje«. U definicijama se naime pojavljuju temeljni pojmovi, ali definicija kao takva »daje samo okvir i pravilo za istraživanje dotičnoga bića «, ${ }^{17}$ za njegovo znanstveno propitivanje. Stoga sredstvima svoje specifične teorije i metode znanosti nikada nisu u stanju »sebe same pred-staviti kao znanosti ${ }^{18}$ A pogotovo se iskazi o biću kao takvome, o bitku bića, ne samo ne mogu »dokazivati, nego se ne mogu primjereno ni misliti « ${ }^{19}$ pojmovima i dokazima pojedinačnih znanosti. Jer, one se uvijek kreću unutar određenog tumačenja smisla bitka, tako da njima svako drugo iskustvo bitka ostaje nedostupno. Samo dakle ako se mišljenje na prvom mjestu shvati u ovom značenju, onda se možda s pravom može reći da »znanosti ne misle «. ${ }^{20}$ One naime istražuju i znaju samo biće.

A ako u suvremenom svijetu dominiraju prirodne znanosti koje žele prije svega spoznati biće, a ne misliti bitak, i ako je očito da su u tom svijetu i humanističke znanosti opterećene novovjekovnim metafizičkim subjektivističko-objektivističkim definiranjem, zapravo fiksiranjem čovjeka kao animal rationale, pri čemu to fiksiranje nije nikakvo »bitno pitanje«, nego neupitan odgovor, čini se primjerenim postaviti pitanje je li i kako je na tragu ovih razmišljanja o mogućem prirodoznanstvenom znanju o biću i o mišljenju istine bitka, koje se u ovom kontekstu gotovo nužno nameće, kao i na tragu razmišljanja o novovjekovnom razumijevanju čovjeka i iz njega proizišlog poimanja spoznaje bića uopće, moguće razriješiti dvojbe oko toga čemu humanističke znanosti u suvremenom svijetu i što bi one mogle i trebale biti?

Kao humanističke, odnosno duhovne, obično se smatraju one znanosti koje se ne pribrajaju matematici i prirodnim znanostima. U svojim razmišljanjima o njima Wilhelm Dilthey ih je razlikovao od prirodnih prije svega po tome što je za njega temeljni pojam duhovnih razumijevanje, a prirodnih razjašnjavanje. No, on očito nije bio u stanju izvršiti zadaću koju je sebi postavio, a to je da spoznajnoteorijski opravda posebnost duhovnih znanosti i tako ih učini jednakovrijednima prirodnim. A možda je i sama zadaća pošla od krivih pretpostavki prema kojima je glavno pitanje razumijevanja stvarnosti spoznajnoteorijsko, nerijetko reducirano na znanstveno znanje o biću, iz kojega je isključeno mišljenje istine bitka u njegovoj neiscrpivosti i vremensko-povijesnoj dimenziji i u kontekstu njegova odnosa prema čovjekovu tubitku, što bi možda moglo i trebalo biti temeljno pitanje filozofije.

\footnotetext{
${ }^{17}$ Martin HEIDEGGER, Einleitung in die Philosophie, GA 27, Frankfurt a. M., Vittorio Klostermann, 1996, 193.

${ }^{18}$ Heidegger, Vorträge und Aufsätze..., 60.

${ }^{19}$ Heidegger, Nietzsche I, GA 6,1, Frankfurt a. M., Vittorio Klostermann, 1996, 468.

${ }^{20}$ Vetter, Grundriss Heidegger..., 142.
} 
Stoga je razumljivo što Heidegger u ovom kontekstu ide drugim putevima, iako i Diltheyu ima zahvaliti vlastite misaone poticaje, osobito pri promišljanju vremenitosti i povijesnosti, nakon što je Edmund Husserl povratak životu učinio univerzalnom radnom temom i napustio sužavanje problematike na pitanje o metodi duhovnih znanosti, a koje je analogno pitanju o metodi prirodnih znanosti. Husserlova analiza svijeta života i konstituiranja smisla, koje stvara tlo za iskustvo, dala je naime pitanju o objektivnosti u duhovnim znanostima novu pozadinu, te učinila da se pojam objektivnosti znanosti pojavi kao poseban slučaj. Tako znanost nije neka činjenica od koje bi trebalo poći, nego konstitucija znanstvenoga svijeta ima zadaću razjasniti idealiziranje koje je zadano znanošću kao takvom. Pritom se pri povratku na djelatni život suprotnost prirode i duha pokazuje kao nešto što nema zadnju vrijednost, budući da se i duhovne i prirodne znanosti izvode iz djelatne intencionalnosti univerzalnoga života. $^{21}$

Heidegger je pak u svjetlu pitanja o bitku, koje je on na svoj način ponovno probudio, svemu tome dao nov i radikalan zaokret. On pritom slijedi Husserla i misli da povijesni bitak ne treba u Diltheyevu smislu razlikovati od bitka prirode, da bi se spoznajnoteorijski legitimirala metodička posebnost povijesnih znanosti. Za njega je naime način spoznavanja prirodnih znanosti samo vrsta razumijevanja, »koja je zalutala u opravdanu zadaću shvaćanja onoga prisutnoga u njegovoj bitnoj neshvatljivosti«.22 Pritom razumijevanje nije nikakav rezignacijski ideal ljudskog životnog iskustva, kao kod Diltheya, ili zadnji metodički ideal filozofije u odnosu na naivnost življenja kao takvoga, kao kod Husserla, nego izvorna forma događanja tubitka, njegov bitak-u-svijetu. Prije svakoga diferenciranja u različite pravce razumijevanje je dakle način bivstvovanja tubitka, ukoliko je on onaj vremenski moći biti (Seinkönnen). Čovjek se naime može razumjeti samo kao vremenito i povijesno biće koje se događa u svijetu.

A na pozadini Heideggerovih razmišljanja, posebno onih koja tematiziraju razliku između prirodoznanstvenog znanja o biću i o mišljenju istine bitka, čiji je zaborav snažno etabliralo novovjekovno metafizičko filozofiranje i taj zaborav radikaliziralo u kontekstu razumijevanja čovjeka kao animal rationale i u kontekstu isticanja njegove subjektivističko-objektivističke dimenzije, Hans-Georgu Gadameru se postavlja pitanje što za razumijevanje i samorazumijevanje čovjeka znači ako on zna da je nošen poviješću koja je artikulirana $\mathrm{u}$ jeziku, što je njega vodilo prema ontološkom zaokretu hermeneutike na niti vodilji jezika. A ovaj zaokret stoji i u svezi s njegovim ishodišnim problemom, s pitanjem duhovnih znanosti i njima primjerene hermeneutike, što za Heideggera ipak nije bila izvorna nakana. Ovaj je naime, na osnovi svoga izvornijeg

\footnotetext{
${ }^{21}$ Usp. Hans-Georg GADAMER, Wahrheit und Methode. Grundzüge einer philosophischen Hermeneutik, GW 1, Hermeneutik I, J. C. B. Mohr (Paul Siebeck), Tübingen, UTB, 1999, 263.

${ }^{22}$ Martin HEIDEGGER, Sein und Zeit, Tübingen, Max Niemeyer Verlag, ${ }^{17} 1993,153$.
} 
polazišta, hermeneutičke fenomenologije faktičnosti, razumijevanje duhovnih znanosti označio kao nešto izvedeno. Uostalom, za njega je dizanje razumijevanja na razinu metodološkog puta duhovnih znanosti izraz bezidejnosti u kojoj se našao historizam, povratak prema metodiziranju razumijevanja i očajnički pokušaj da se $s$ obzirom na sve jače nadolazeće prihvaćanje vremenitosti, povijesnosti i konačnosti čovjeka i njegove spoznaje, pronađe neko čvrsto uporište. A ideja nekog čvrstog bezvremenskog temelja potječe od čovjekova bijega od vremenitosti, predodžba pak da postoji neka apsolutna istina zapravo od potiskivanja istine. Zbog toga uvijek nanovo ističe da je potrebno uvažavati dimenziju konačnosti i vremenitosti, kao i predrasudu kao pozitivnu ontološku značajku razumijevanja, ${ }^{23}$ te shvatiti da apsolutno »objektivno«, neprotuslovno razumijevanje stvarnosti nije moguće.

Stoga je neosporno da je Gadamerovo razumijevanje duhovnih znanosti blisko Heideggerovu mišljenju, iako se on oslanjao i na Diltheya tako što je ponovno pokrenuo pitanje njihove istine. On je naime, poput Heideggera, temeljito stavio u pitanje važnost metode pri legitimiranju duhovnih znanosti, pa je njihovu istinitost pokušao ilustrirati umjetničkim djelom, gdje objektivirajući metodički način promatranja nije ni smislen ni moguć, budući da on previđa istinu spoznaje koja se može postići na ovaj način. Stoga je očito da Gadamerovo isticanje ontološke funkcije umjetničke istine slijedi Heideggerov »Izvor umjetničkog djela«. ${ }^{24}$

No, čini se da Gadamer ipak ne prihvaća Heideggerov prigovor iz »Pisma o humanizmu " protiv tradicionalnog humanizma, prema kojem je ovaj posljedica metafizičkog mišljenja koje želi ovladavati bićem, budući da je on usredotočen na čovjeka, a ne na bitak. Stoga u »Istini i metodi« ističe značenje humanističke tradicije za duhovne znanosti i nastoji pokazati da su njezini pojmovi, kao što su obrazovanje, sensus communis, rasudbena moć i ukus, odlučujući za konstituiranje primjerenog pojma razumijevanja i istine. ${ }^{25} \mathrm{No}$, on pritom argumentira i protiv ideje, za koju se bore historizam i pozitivizam, da duhovne znanosti trebaju izraditi vlastite metode da bi smjele uživati status znanosti, te se pita je li ovdje stvarno na mjestu traganje za nekom apsolutnom sigurnošću, ${ }^{26}$ koju valja zahvaliti sigurnoj metodi, i pritom sugerira da se »ono znanstveno« $u$ duhovnim znanostima više nalazi u psihološkom taktu »nego u metodi «. ${ }^{27}$

Tako dakle Gadamerovo mišljenje postaje načelna kritika opsjednutosti metodom pri promišljanju znanstvenosti duhovnih znanosti. Pritom je njegova ishodišna teza da se ono što njih čini znanostima prije može razumjeti

\footnotetext{
${ }^{23}$ Usp. Jean GRONDIN, Einführung in die philosophische Hermeneutik, Darmstadt, Wissenschaftliche Buchgesellschaft, ${ }^{2} 2001,152-153$.

${ }^{24}$ Usp. Jean GRONDIN, Heidegger und Hans-Georg Gadamer. Zur Phänomenologie des Verstehens-Geschehens, u: Thomä (izd.), 384.

${ }^{25}$ Usp. isto, 387.

${ }^{26}$ Usp. Grondin, Einführung in die philosophische Hermeneutik..., 153-154.

${ }^{27}$ Gadamer, Wahrheit und Methode..., 13.
} 
»iz tradicije pojma obrazovanja« nego »iz ideje moderne znanosti «. ${ }^{28} \mathrm{U}$ ovoj naime tradiciji izgrađeni pojmovi primjereni su spoznajnoj potrebi duhovnih znanosti, a prije Kanta su bili vrlo prisutni. Stoga se on gotovo s negodovanjem pita »kako je došlo do nestajanja ove tradicije i kako je time istinitost duhovnoznanstvene spoznaje potpala pod njoj strano mjerilo mišljenja metode moderne znanosti ${ }^{29}$ kako i zašto je i ovdje došlo do dominacije prirodnih znanosti i njihove metode?

Razlog za ovo Gadamer vidi prije svega u estetiziranju temeljnih pojmova humanizma, na prvom mjestu rasudbene moći i ukusa, kojima je u prijašnjim vremenima pripadala i spoznajna funkcija, što je zapravo bilo posljedica djelovanja Kantove »Kritike rasudbene moći«, koja je subjektivirala i estetizirala ukus i odrekla mu spoznajnu vrijednost. Ono naime što nije primjereno mjerilima objektivnih i metodičkih prirodnih znanosti pritom vrijedi kao subjektivno i estetsko, odvojeno od spoznaje. A time što je subjektiviranje pojma ukusa diskreditiralo svaku teorijsku spoznaju, osim onu prirodnih znanosti, samoodređenje duhovnih znanosti gurano je "prema oslanjanju na nauku o metodi prirodnih znanosti «. ${ }^{30}$ Stoga se i od duhovnih znanosti očekuje da ostvare »slično ovladavanje ljudsko-povijesnim svijetom«, možda čak i više od toga, otkako ovladavanje prirodom »više povećava nego smanjuje nezadovoljstvo kulturom«. Naime, prirodoznanstvene metode ne zahvaćaju sve ono što bi bilo vrijedno znati, one ne zahvaćaju »zadnje svrhe kojima bi imalo služiti sve ovladavanje sredstvima prirode i čovjeka «, jer tu nije riječ o onom zajedničkom, o onome »što predstavlja uporaba znanstvenih metoda za svu znanost«, nego o onom jedinstvenom, što duhovne znanosti čini »značajnima i razmišljanja vrijednima «, ${ }^{31}$ o onome što kao istina bitka i istina čovjeka kao tubitka, unatoč svim spoznajama, ostaje zagonetnim i tajanstvenim.

A ono jedinstveno, posebno ono jedinstveno čovjeka i njegove egzistencije, njegova tubitka u odnosu prema bitku, njegove humanosti odnosno duhovnosti, Heidegger ilustrira svojim razmišljanjem o razlici između egzaktnosti znanja prirodnih znanosti i neegzaktnosti onoga što trebaju znati, odnosno misliti humanističke znanosti, ako ih se uopće može zvati znanostima. Prema njemu, fizika je općenito spoznaja prirode, a specifično spoznaja onoga tjelesnoga u njegovu pokretu, što se »neposredno i stalno, iako na različite načine, pokazuje na svemu što je prirodno«. Ako pak fizika postane matematička, onda to znači da njome i preko nje »ono već-poznato unaprijed« mora biti utvrđeno. Ovo pak utvrđivanje u biti je »nacrt onoga što za traženo spoznavanje prirode ubuduće treba biti priroda«, što je u novovjekovnoj fizici u sebi zatvorena «po-

\footnotetext{
${ }^{28}$ Isto, 23.

${ }^{29}$ Isto, 29.

${ }^{30}$ Isto, 47.

${ }^{31}$ Gadamer, Wahrheit in den Geisteswissenschaften, u: Wahrheit und Methode, GW 2, Hermeneutik II, 37.
} 
vezanost pokreta točaka mase, koje su prostorno-vremenski u odnosu« ${ }^{32}$ Ovaj pak nacrt svoju sigurnost dobiva tako što se »fizikalno istraživanje za svaki od svojih istraživačkih koraka unaprijed « mora vezati na njega. A ovo vezanje i ova strogost istraživanja uvijek ima »vlastiti karakter«, imaju strogost matematičke prirodne znanosti u smislu egzaktnosti. Nasuprot tome duhovne znanosti, pa i sve znanosti o onome živome, »da bi ostale stroge«, nužno moraju »biti neegzaktne«. Ako se naime ono živo shvaća kao prostorno-vremenska veličina pokreta, što je potpuno legitimno, onda se tu »više ne zahvaća« ono što je živo. Stoga neegzaktnost historijskih znanosti, koje žele shvatiti ono živo, nije neki nedostatak, nego »ispunjenje bitnog zahtjeva koji postavlja ovaj način istraživanja«. Pritom nacrt i osiguranje predmetnog područja ovih znanosti ne samo da je druge vrste, nego je $i$ »puno teže od provedbe strogosti egzaktnih znanosti «. ${ }^{33}$

Stoga se na kraju može postaviti pitanje zašto bi misaoni napori u humanističkim znanostima bili manje nužni, manje smisleni i manje vrijedni od onih u prirodnim znanostima. Jer, i u jednima i u drugima je riječ o čovjekovu traganju za osmišljavanjem postojanja u svijetu, o samotraženju i samonalaženju, pri čemu je on uvijek na putovanju, koje on, kao vremenito i povijesno biće, kao svojevrstan bitak za smrt, nikada ne može zaključiti, pa onda ni egzaktno spoznati. Stoga se na pitanje, čemu humanističke znanosti u vrijeme dominacije prirodnih znanosti, možda može dati vrlo jednostavan odgovor: Što je veća dominacija prirodnih, tim je veća potreba za humanističkim, budući da one pokušavaju odgovarati na pitanja do kojih prirodne znanosti ne dopiru. One se naime pitaju o tome što je znanost, a što znanje, što je biće i njegova istina, a što bitak i njegova istina, što je mišljenje, a što spoznavanje, što je sigurnost, a što nesigurnost, što je egzaktnost, a što neegzaktnost, što smisao, a što besmisao. A sve to, s dubokom sviješću o vremenitosti i povijesnosti svega, pa i svakoga pitanja i odgovora o onome što jest i kako jest.

\footnotetext{
${ }^{32}$ Martin HEIDEGGER, Die Zeit des Weltbildes, u: Holzwege, Frankfurt a. M., Vittorio Klostermann, ${ }^{6} 1980,76$.

${ }^{33}$ Isto, 77.
} 


\section{Ivan Kordić* \\ Wozu Humanwissenschaften im Zeitalter der Dominanz der Naturwissenschaften?*** \\ Zusammenfassung}

In der Frage nach den Humanwissenschaften im Zeitalter der Dominanz der Naturwissenschaften scheint es unerlässlich zu sein, vor allem die Frage nach Wissen und Denken des Menschen überhaupt zu stellen. Dabei wird man vielleicht schnell zur Einsicht kommen, dass diese Frage keine einfachen und einseitigen Antworten duldet, was nicht nur die Geschichte des Wissens und des Denkens, die Geschichte der Wissenschaft und der Philosophie mit ihrer unendlichen Unerschöpflichkeit bezeugen, sondern auch die in der modernen Welt trotz allem Wissen stark vorhandene Überzeugung, dass der Mensch und seine Welt doch ein Rätsel, ein Geheimnis bleiben. Deswegen sind sowohl die modernen Naturwissenschaften als auch die modernen Geisteswissenschaften in ihren Methoden und in ihren Erkenntnissen im hohen Maße unsicher, so sehr sie nicht selten Sicherheit spielen und so sehr sie, besonders die Naturwissenschaften, das Bedürfnis haben, bewusst oder unbewusst den Eindruck der absoluten und fraglosen Dominanz zu hinterlassen. Damit aber sowohl die einen als auch die anderen ihren Beitrag zum Verstehen und zum Erkennen dessen, was ist, leisten können, ist es notwendig, im möglichst hohen Maße auf ideologisch-dogmatische Irrtümer der Vergangenheit und der Gegenwart zu verzichten und sich der hermeneutisch-phänomenologischen Suche nach der Wahrheit des Seins zuzuwenden, mit vollem Bewusstsein, dass sie zeitlich und geschichtlich, endlich und begrenzt ist, dass sie sich auf verschiedene Weise und immer neu sowohl verbirgt als auch zeigt.

Schlüsselworte: Humanwissenschaften, Naturwissenschaften, Wissen, Denken, Wahrheit.

(na njem. prev. Ivan Kordić)

\footnotetext{
* Prof. Dr. Ivan Kordić ist ordentlicher Professor, Wissenschaftsrat am Institut für Philosophie; Anschrift: Institut za filozofiju, Ulica grada Vukovara 54, HR-10000 Zagreb; E-Mail: ivan.kordic1@zg.htnet.hr.

** Dieser Vortrag wurde auf dem Symposium des Instituts für Philosophie mit dem Thema »Der Sinn der Humanwissenschaften « gehalten, das im Palais von Matica hrvatska, Zagreb, den 10. Dezember 2015, stattgefunden hat. Der ganze Text wird im Sammelband des Symposiums veröffentlicht werden.
} 